\title{
The Demise of Universality: \\ Federal Financing for Post-Secondary Education in Canada ${ }^{1}$
}

\author{
Paul Weaver, Simon Fraser University \\ Department of Political Science, M.A. Candidate
}

This paper has two central objectives. Generally, its purpose is to trace the trajectory of the fiscal relationships that exist between Canada's two orders of government. In particular, the main focus is on the linkages financing post-secondary education. Towards that end, the paper is structured on a broad canvas in the following manner. First, the concept of federalism is examined, which establishes the theoretical context underpinning the intergovernmental relationships in Canada. Next, the different types of transfers between the federal and provincial government that finance post-secondary education are investigated arguing that the imprecision of these arrangements obscures lines of accountability for post-secondary education as outlined in the constitution. And third, the implications of these arrangements for the provision of educational services are traced in order to suggest that recent developments in the funding regimes are the product of changing federal policy preferences that favour economic efficiency over social cohesion. Overall then, this paper suggests that although post-secondary education is an area of provincial jurisdiction, the fiscal arrangements that finance this area of social policy have altered the nature of its delivery. As such, recent changes to the funding

\footnotetext{
${ }^{1}$ A portion of the title is borrowed from an article by Dr. Stephen Phillips, "The Demise of Universality: The Politics of Income Security in Canada, 1978-1993.” A paper submitted to the Annual Meeting of the

Weaver, Paul. "The Demise Of Universality: Federal Financing for Post-Secondary Education in Canada.” Federal Governance: A Graduate Journal of Theory and Politics. 4.1 (2004)

<http://www.cnfs-rcef.net/federalgovernance/content/volume4/articles/Paul_Weaver.pdf>
} 
regimes represent a shift in policy orientation from one previously based on a panCanadian universality to a policy more oriented towards individuals and their ability to pay.

\section{Federalism, the Division of Powers and Post-Secondary of Education - Who's Responsible for What?}

Within the rubric of political discourse, numerous taxonomies have been proposed to conceptualize an authoritative definition of a federal system. K.C. Wheare for instance, offers the classical definition of federalism as a system of governmental organization, which assigns constitutional responsibilities to two different orders of government—central and regional. According to Wheare, the divided powers are such that each is sovereign in its own area of constitutional competence, with neither being subordinate to the other. ${ }^{2}$ Similarly, Whittington and Van Loon argue that federalism contends with intergovernmental sovereignty. For them, sovereignty is also divided among two orders of government, establishing legislative powers limited to those areas allotted to them in the constitution. ${ }^{3}$ Taken together, these explanations sketch the complexity regarding federal systems of governance. ${ }^{4}$ For this inquiry, the concept of federalism and the division of local and national policy responsibilities offered above is suggested as an analytic device in which to assess the legislative powers in Canada, and in particular, those responsible for post-secondary education.

British Columbia Political Studies Association, The University of Victoria, Victoria BC, May 5-6 2000: 128.

${ }^{2}$ K.C. Wheare, Federal Government, $4^{\text {th }}$ ed. (London: Oxford University Press, 1963$): 10$.

${ }^{3}$ Michael Whittington and Richard J. Van Loon, Canadian Government and Politics: Institutions and Processes (Toronto: McGraw-Hill Ryerson, 1996): 130.

${ }^{4}$ Harvey Lazar lists four reasons why Canada is one of the most decentralized, non-interdependent and non-hierarchically organized federations in the world; (1) the constitution lists only three concurrent powers; (2) both orders of government have taxation powers: (3) some elements of the central governments power have fallen into disuse [e.g. reservation and disallowance]; and (4) comparatively, there are few conditions on the fiscal transfers to the sub-levels of government. In Harvey Lazar, "The Social Union Framework Agreement and the Future of Fiscal Federalism," Canada: The State of the Federation (1999/2000): Toward a New Mission Statement for Canadian Fiscal Federalism. Ed. Harvey Lazar. 
Enumerating powers between two orders of government in Canada was, among other things, conceived as a way to manage political discord between the French and English in British North America. ${ }^{5}$ Initially, this bi-cultural compromise safeguarded distinct cleavages in the new Dominion. However, Monahan notes that the allocation of legislative responsibility “did not establish Canada as a true federal union.”“ In fact, several aspects of the Constitution Act, 1867 indicate the constitutional framers intended the central government to occupy a superior status, ${ }^{7}$ which has given rise to lasting challenges between the two orders of government. ${ }^{8}$

The division of legislative powers between the two orders of government is detailed in Sections 91 through 101 of the Constitution Act, 1867. ${ }^{9}$ Section 91 enumerates the federal powers, and consists of two parts. Part one describes a general grant of power to the federal parliament, known as the "Peace, Order and Good Government” clause, while Part two lists twenty-nine exclusive federal policy areas. ${ }^{10}$ Section 92 assigned sole responsibility for sixteen policy matters to the provincial governments. ${ }^{11}$ Section 93 allocates responsibility for education ${ }^{12}$ to the provinces,

Kingston: Institute of Intergovernmental Relations, 1999: 99-128. Available online at:

$<$ http://qsilver.queensu.ca/iigr/publications/recent_publications/lazar_chapter.pdf $>$ : 13-14.

${ }^{5}$ See Edwin Black's five different conceptions of Canadian federalism in Patrick J. Smith’s Law, Politics and the Administration of Justice: Canadian Cases, Comparative Perspectives, Vancouver: Pacific Policy Press, 1997: 57-65.

${ }^{6}$ Patrick J. Monahan, Constitutional Law, Concord ONT: Irwin Law, 1997: 97.

${ }^{7}$ For instance, the residual Disallowance, Reservation and Declaratory powers endowed the Federal government with the authority to virtually nullify provincial legislation. See Rand Dyck, Canadian Politics: Critical Approaches, $2^{\text {nd }}$ ed. Scarborough: Thompson, 1996: 69-77.

${ }^{8}$ This paragraph has been paraphrased from Paul Weaver, Fiscal Federalism and Social Policy in Canada: The Financing of Structural Adjustment, Term Paper for POL 324, 1 March, 2002: 4, 5.

${ }^{9}$ Three special provisions of the Constitution Act - sections 109 (where the provinces were given full title to "All Lands, Mines, Minerals, and Royalties" within their boundaries), 121 (describing unfettered trade of "All Articles of the Growth, Produce, or Manufacture" between the provinces), and 132 (the federal Treaty power) - was allocated to the federal government and hence, could also be argued to be federal.

${ }^{10}$ For example, ss.91 (1); "The Regulation of Trade and Commerce, ss. 91(3); The raising of Money by any Mode or System of Taxation and ss.91 and ss (4); The borrowing of Money on the Public credit.

${ }^{11}$ For example, ss.92 (2) "Direct taxation," ss.92, (3) "The borrowing of Money on the sole Credit of the Province,” and ss. 92 (7) "The establishment, Maintenance, and Management of Hospitals.” 
subject to four provisions. ${ }^{13}$ Section 95 describes two concurrent powers, agriculture and immigration, while sections 96 through 101 relate to the judiciary. ${ }^{14}$

As Canada became increasingly industrialized, debates emerged regarding the utility of higher education and whether its provision should be an individual or government responsibility. For example, some have argued that post-secondary education enables individuals to access greater social and economic opportunities; ${ }^{15}$ that is, whether higher education is a vehicle for social and economic advancement. According those who subscribe to this view, the provision of post-secondary education is a societal responsibility and as such, ought to be administered by government. Others ${ }^{16}$ however, assert that higher education should be an individual, not societal responsibility, arguing that it is the individual themselves that receives the most benefits from a postsecondary education. In this instance, the federal government realized that a university education underpins social and economic development, representing a long-term societal investment. ${ }^{17}$ Acting on this recognition, after the turn of the twentieth century Ottawa embarked on several initiatives to ensure increased access to this resource. ${ }^{18}$

\footnotetext{
${ }^{12}$ At Confederation, this meant responsibility for religious or denominational schools.

${ }^{13}$ Here, Whittington and Van Loon argue that section 93 established limitations on the exercise of this power by the provinces. According to them, the limitations translate into education being a concurrent shared - policy area between the two levels of government, endowing the federal government with the power to "police" and "protect" the rights of religious minorities. Whittington and Van Loon, 198.

${ }^{14}$ Weaver, 5.

${ }^{15}$ Terry Witherspoon, "The Dynamics of Social Inclusion and Exclusion in Public Education,” The Canadian Council on Social Development, available at: [www.ccsd.caq/subsites/inclusion/bp/tw.htm], n.d.

${ }^{16}$ Page 53 of Andrew J. Coulson, "Market Education and the Public Good," Can the Market Save our Schools? Claudia R. Hepburn ed. Vancouver: The Fraser Institute, 2001: 53-72. Available online at: $<$ http://www.fraserinstitute.ca/publications/books/market schools/5_coulson.pdf >, 2001.

${ }^{17}$ Benjamin Levin and Nancy Sullivan, Governments and Universities, Vol., XVIII - 1 (1988): 1, 2.

${ }^{18}$ Derek Hum and Frank Strain, "Fiscal Transfers, Horizontal Equity and Post Secondary Education," The Canadian Journal of Higher Education. XVIII (2): 1988, document several federal laws that targeted specific policy sectors and demographic groups (the 1913 Agricultural Instruction Act, the 1919 Technical Education Act, the 1937 Unemployment and Agricultural Assistance Act and the Youth Training Act in 1939) that arose out of the 1910 Royal Commission on Industrial Training and Vocational Education with the objective of stimulating economic growth; 18,19 .
} 


\section{Fiscal Federalism and The Financing of Higher Education}

Many of the powers listed in section 91 of the Constitution Act, 1867 granted the federal government extensive levers over the economy and other areas of national concern. In addition, the constitution also endowed the provinces with the legislative and regulatory responsibility for matters of local importance. At times, this division of responsibility has led to competition between federal and provincial policy domains. In many instances, taxation, the means to raise revenue for policy expenditures to finance social policy areas such as post-secondary education for example, has been especially problematic. Under the original Constitution, the provinces were limited to direct taxation powers only - listed in section 91 (2) and (3) of the Constitution Act, 1867 which impinged on their capacity to raise revenue. In contrast, the federal government suffered no such limitations. It was able to 'raise money by any mode of taxation.' This broad fiscal capacity gave Ottawa virtually unfettered power to raise revenues, levy indirect taxes and to exert sweeping influence over provincial policy expenditures like post-secondary education. Brown for instance, argues that the scope of Ottawa's taxation and spending powers, gave the federal government "a right to spend in any field" it saw fit. ${ }^{19}$ Over the course of Canada's federal maturity, this perceived right has necessitated

\footnotetext{
${ }^{19}$ Douglas Brown, "Fiscal Federalism: The New Equilibrium Between Equity and Efficiency," Canadian Federalism: Performance, Effectiveness and Legitimacy, Herman Bakvis and Grace Skogstead eds. Don Mills: Oxford, 2002: 60. The Spending Power: although the constitution endowed both levels of government with taxation powers, the federal government enjoyed greater revenue raising capacity, due to its ability to tax directly, while the provinces were only allowed to tax indirectly - this asymmetrical taxation regime, lead to a series of "checkerboard" taxation systems between different provinces. The taxation agreements during the war harmonized the tax system; however, the provinces were still left with an insufficient level of revenue to deliver the social services of an emerging welfare state.
} 
a series of complex arrangements in which the two levels of government have combined forces to coordinate and finance post-secondary education. ${ }^{20}$

Prior to World War Two, post-secondary education was not considered an especially noteworthy area of provincial jurisdiction. In fact, Hum and Strain report that most post-secondary institutions relied on tuition fees and private donations to finance their operations, ${ }^{21}$ rather than any kind of government subsidy. This commonly meant institutions of higher learning were the exclusive domain of wealthy elite's who could afford to pay the tuition fees in order to attend.

After World War Two, the federal government initiated its first level of involvement in post-secondary education. As part of the post-war Keynesian consensus, the federal government initiated numerous spending endeavors in areas of provincial jurisdiction to support post-secondary institutions. ${ }^{22}$ In 1945 for example, the Veterans Rehabilitation Act established a grant program for Canadian soldiers returning from the war. These grants enabled veterans to attend Canadian post-secondary education institutions with little or not out of pocket cost; ${ }^{23}$ however, despite the positive aspects of this initiative, some side effects for the division of powers also occurred. For instance, many institutions of higher learning across the country experienced increased levels of enrollment and revenues during this time, which was chiefly due to the grants to the returning Veterans, which signified the beginning of a federal stamp on that provincial

20 Brown, 64-65; Paul Barker, “Disentangling the Federation: Social Policy and Fiscal Federalism,” Challenges to Canadian Federalism, Martin Westmacott and Hugh Mellon eds. Scarborough Ont: Prentice 1998: 144.

${ }^{21}$ Hum and Strain, 22.

${ }^{22}$ Harvey Lazar, "In Search of A New Mission Statement for Canadian Fiscal Federalism,” Canada: The State of the Federation (1999/2000): Toward a New Mission Statement for Canadian Fiscal Federalism, Harvey Lazar ed. Kingston: Institute of Intergovernmental Relations, 1999: 8-10. Available online at: $<$ http://qsilver.queensu.ca/iigr/publications/recent_publications/lazar_mission_statement.pdf $>$.

${ }^{23}$ Hum and Strain, 22. 
policy area. ${ }^{24}$ As the twentieth century progressed, the nature of the federal government's involvement would become increasingly explicit. For the most part, this resulted as Ottawa began to use the power of its purse to shape the nature of provincial funds directed toward post-secondary education.

\section{A Paradigm Shift; or two, or three...}

In the decades that followed the Second World War, the fiscal relationships between institutions of higher learning and both levels of government underwent many changes. Three phases of intergovernmental funding emerged during this time. First, from the 1950s to late 1960s, the federal government adopted a nation building strategy of panCanadian initiatives to help facilitate the post-war economic expansion. This relationship was characterized by a brief period of direct block grants to individual institutions that not only augmented their individual operating costs but also supplied the labour market with a steady supply of skilled graduates. Second, from the 1960s until the early 1990s, a series of cooperative, intergovernmental arrangements sustained a criterion of national standards for access to post-secondary institutions within the different provinces developed. And last, acute fiscal and economic exigencies created by public concern over a rising deficit and continental integration in the early 1990's necessitated a hasty federal withdrawal from many shared policy areas including post-secondary education.

Acting on the 1951 Royal Commission on National Development for the Arts, Letters and Science, the federal government established per-capita funding transfers known as block grants to fund institutions of higher education. ${ }^{25}$ The grants transferred funding directly to the institutions themselves, rather than to individuals as with the

${ }^{24}$ Ibid. 
Veterans Act funding. This funding shift reinforced the federal toehold in that area of provincial jurisdiction.

In the 1960's, another per-capita grant system emerged to further alter the intergovernmental arrangements funding post-secondary education. Due to the nature of the per capital funding, increased enrolments and limited revenues at this time, institutions in different provinces began to offer irregular levels of access and quality of service. Provinces like Nova Scotia for instance, with small populations and tax bases experienced difficulty providing adequate levels of access to their residents as demand for entry into post-secondary institutions increased. Alternatively, Ontario, which received larger grants because of their larger population, suffered no such difficulties. In essence, the per-capita transfers established an asymmetrical system of policy development, whereby the larger provinces with more institutions, received more funding and were thus able to provide higher quality services than the smaller, less populated provinces. In sum, a "patchwork" of policies developed.

The per-capita grants from the federal government to post-secondary institutions ended in the late 1960s. In their place, the federal government began to transfer postsecondary education funding directly to the provincial governments. And in turn, the provinces issued individual operating grants to the institutions in $1967 .^{26}$ This shift in funding translated into the provinces receiving an unconditional block transfer from the federal government consisting of cash and tax points, which represented fifty percent of the operating grants of the post-secondary institutions. According to Barker, these grants

\footnotetext{
${ }^{25}$ Barker, 146.

${ }^{26}$ Hum and Strain, 23.
} 
were issued with the expectation that the provinces would pay for the remaining $50 \%$, ${ }^{27}$ this arrangement was known as a cost-sharing or 50/50 funding arrangement. The 50/50 spending formula established a system of financing higher education where the provincial government was expected to pay 50\% of the operating costs of the post-secondary institutions and the federal government 50\%, without any of the other "conditions" placed on social initiatives such as social welfare or health care; ${ }^{28}$ however, despite the increasing scope of federal involvement in this area, it did not have the constitutional authority to regulate the institutions specifically or policy domain in general-this responsibility continued to fall to the provinces. ${ }^{29}$

Despite the increased flow of revenues that accompanied the new funding regime, the design of the agreements was flawed. For example, because the 50/50 funding formula was a federal initiative that intersected an exclusive area of provincial jurisdiction, Hancock ${ }^{30}$ and Barker argue the arrangements became a flashpoint for intergovernmental tension. For some observers of this funding mechanism, the 50/50 formula was a pliable funding device that not only ensured each province had a secure source of funding for higher learning but also gave them enough flexibility to decide where the funding would go. Paul Barker for example, argues that the pan-Canadian agreements were established with the consent of the provinces and in doing so, increased funding levels ensured reasonable levels of access to post-secondary institutions. ${ }^{31}$ Others, however, have argued the 50/50 financing arrangement was simply a way for the

\footnotetext{
${ }^{27}$ Barker, 147.

28 Dyck, 77. In addition, on pages 19 and 20, Hum and Strain catalogue the origin of the cost-sharing agreements, asserting they emerged from the 1927 Old Age Pension Plan in which the federal government reimbursed the provinces "\$0.50 cents for every $\$ 1.00$ spent on old age pensions: the so-called 50/50 formula."

${ }^{29}$ Weaver, 8.

${ }^{30}$ Dave Hancock, “Designing a New Social Framework for Canadians,” Policy Options (Nov 1998): 17-20.
} 
federal government to invade areas of provincial jurisdiction. In this instance, Baier argues the fiscal transfers to the provinces allowed "the federal government to infiltrate areas of provincial jurisdiction, ${ }^{, 32}$ and triggered partisan conflicts between Ottawa and the provinces. In particular, many of these tensions developed between the two levels of government regarding the connection between the federal government's spending in areas outside of its jurisdiction and the constitutional responsibility for an emerging social union. ${ }^{33}$

In addition to the intergovernmental tension, the new funding arrangements to the provinces also established some unintended consequences. For instance, vertical fiscal imbalances between institutions in different provinces started to emerge. These imbalances occurred in two different ways: first in terms of access to post-secondary institutions and second, quality of educational services provided. In the first instance, since the original federal funding was calculated on a per-capita basis and transferred revenue directly to the institutions, provinces with larger populations and more institutions received higher levels of federal funding and were therefore endowed with the capacity to delivery better services. And in the second case, because the transfer of funds and tax points were of a block variety, the new changes did not provide the provincial governments any inducements to sustain adequate levels of service delivery. Consequently, when demand increased, the provinces began to struggle to deliver in the

\footnotetext{
${ }^{31}$ Barker, 147.

${ }^{32}$ Gerald Baier, "Judicial Review and Canadian Federalism,” in Canadian Federalism: Performance, Effectiveness and Legitimacy, Herman Bakvis and Grace Skogstead eds. Don Mills: Oxford, 2002: 30.

${ }^{33}$ A term that describes the network of shared federal/provincial social programs (e.g. health care, postsecondary education, pensions and welfare) that provides Canadians with equitable levels of access to an array of services that enhance their quality of life. Anne McLellan "Modernizing Canada's Social Union: A New Partnership Among Governments and Citizens," Policy Options (Nov 1998): 8; page 1172 in Kumanan Wilson's "Health care, federalism and the new Social Union," Canadian Medical Association Journal 162 (8) 18 April 2000: 1171-1175.
} 
very policy area allocated to them under the constitution. ${ }^{34}$ Similarly, when the provinces' funding for other areas of social policy fell short, they began to draw on the block grants to make up for the shortfall, which diverted finances away from the postsecondary institutions, ${ }^{35}$ buttressing imbalances in program access.

Starting in the late 1970s, the federal government shifted the federal funding for post-secondary education yet again. By this time, over half of all government spending in areas of social assistance, post-secondary education and health was financed by the federal government. ${ }^{36}$ At this point, spending on social programs came under intense scrutiny. Due to an increased awareness of the deficit, the federal government instituted two changes altering the financing and coordination of post-secondary education in Canada. The first change came in the late 1970s as Ottawa restructured funding arrangements to fight the growing deficit, while the second change came in the mid1990s as huge cuts to the transfer payments that financed provincial social programs such as post-secondary education took place. Both of these changes fundamentally altered the policy orientation of higher education and the role of government in its provision.

In 1977, Ottawa introduced the Established Programs Financing Act (EPF) as an adjustment to the existing structure of financing social policy in Canada. ${ }^{37}$ As a funding mechanism, the EPF consolidated three programs - post-secondary education, medical insurance and hospital insurance - from individual fiscal transfers into one block fund. Under the new arrangement, funding for post-secondary education was transferred to the different provincial governments as a combination of cash transfers and tax points

\footnotetext{
${ }^{34}$ Charles Caccia, "Sovereignty in federal states - differing approaches," Canada - United States Law Journal, 24 (1998): 74.

${ }^{35}$ G.C. Ruggeri, “Vertical Fiscal Imbalances and Renewed Federalism.” Policy Options (Nov 1998): 48.

${ }^{36}$ Hancock, 19.
} 
transferred in lieu of cash, ${ }^{38}$ ending the old 50/50, 'conditional nature' of past

expenditures. Instead, the EPF was designed in such a way that increases to the transfer payments to the provinces for the three programs was indexed; that is, linked to annual growth in the economy and population. ${ }^{39}$ In this way, Ottawa was able to establish a ceiling for its contribution to provincial post-secondary education expenditures and the $E P F$, rather than link itself to escalating provincial spending preferences. ${ }^{40}$

The new funding arrangements yielded a mixed bag of responses from the provinces. For most, the changes were heralded as a victory, translating into greater levels of financial flexibility; however, Ottawa capped the growth of the transfer payments to the provinces by linking their growth to increases in their gross domestic product. $^{41}$ Wilson suggests these changes lead to a "less hierarchical relationship” with the federal government because the block grants reoriented the program-funding system to reflect more policy freedom for the provinces, ${ }^{42}$ which allowed them to concentrate on administering their different higher education needs. Redden on the other hand offers a different view. She argues that the tax point contribution of the EPF was a way for Ottawa to offload some of its spending obligations. According to her, the transfer of tax

\footnotetext{
${ }^{37}$ Harvey Lazar, “The Social Union Framework Agreement and the Future of Fiscal Federalism,” 199,120.

${ }^{38}$ The Established Programs Financing arrangement consisted of three, interrelated components. The first was a block - unconditional - grant. Next, was a tax transfer consisting of $13.5 \%$ of a personal tax transfer and $1 \%$ of corporate income tax. And finally, the last element of the EPF was an equalization component, which sought to equalize provincial disparities in public services. Barker, 147; Candace Redden, Through the Looking Glass: Federal and Provincial Decision- Making for Health Policy. Kingston: Institute for Intergovernmental Relations, 1999. Available at: Queens University, Institute for Intergovernmental Relations, Working Paper Series, Available online at:

$<$ www.qsilver.queensu.ca/iigr/publications/working_paper_series/Redden.html>, 1999: 9; Rand Dyck, Canadian Politics: Critical Approaches $2^{\text {nd }}$ ed, Scarborough: Thompson, 1996: 79; Hum and Strain, 24.

${ }^{39}$ Barker, 147; Hum and Strain, 24.

${ }^{40}$ Dyck, 79.

${ }^{41}$ Weaver, 11.

${ }^{42}$ Kumanan Wilson, "Health care, federalism and the new Social Union," Canadian Medical Association Journal 162 (8) 18 April 2000: 1172.
} 
points is not really a federal contribution. Instead, because of the changes, the provinces simply took responsibility for an area of taxation vacated by the federal government. ${ }^{43}$

By linking the growth of federal transfer payments to annual growth in the provincial economy and population changes in the EPF benefited both Ottawa and the provinces. For Ottawa, the changes established a limit to its spending obligations, while also providing an escape clause ${ }^{44}$ that allowed them to elude an increasingly costly financial relationship with the provinces. ${ }^{45}$ Similarly, the provinces were given the much-needed flexibility to design their own programs. In the end, Ottawa’s spending on post-secondary education began to substantially decline because of the funding changes, which signaled the beginning of a sea change in activity to shift the increasing burden of funding higher education onto the individual provinces.

The second major change to the funding formulas for post-secondary education came with the introduction of the Canada Health and Social Transfer (CHST) in the 1995 federal budget. Over the course of the next several years, the new funding mechanism was a major blow for areas of provincial social policy, including post-secondary education. The CHST was a block grant ${ }^{46}$ consisting of three different parts; one, an “amalgamation of purpose-specific grants" $" 47$ that consolidated post-secondary education,

\footnotetext{
${ }^{43}$ Redden, 9.

${ }^{44}$ Paul A. R. Wilson and France St. Hilaire in The Evolution of Federal-Provincial Fiscal Arrangements: Putting Humpty Together Again, argue that implementing the EPF was a strategic, rather than structural decision, designed to sever the cost-sharing links to provincial expenditures in order to induce the provinces to eventually assume full responsibility for all social programs. Kingston: Institute for Intergovernmental Relations, 1999. Queens University, Institute for Intergovernmental Relations, Working Paper Series, Available at: $<$ http://qsilver.queensu.ca/iigr/publications/recent_publications/hobson_st_hilaire_chapter.pdf $>, 163$.

${ }^{45}$ Baier, “Judicial Review and Canadian Federalism,” 30.

${ }^{46}$ Despite being a block grant, the CHST still imposed conditions on the provinces in order to receive funding. For example, the provinces agreed not to impose residency requirements on those seeking social assistance and must comply with the conditions of the Canada Health Act in order to receive funding for provincial health care services.

${ }^{47}$ Brown, 63.
} 
social assistance and health care expenditures into one "super block fund;"48 two, substantial cuts ${ }^{49}$ to the amount of funds transferred to the provinces; ${ }^{50}$ and three, a plan to eliminate fiscal disparities between provinces. ${ }^{51}$ Under the CHST, federal contributions towards post-secondary education significantly declined over the next five years, falling "behind most other areas of social funding."52 Among other things, much of the cutbacks were due to an ongoing war on the deficit and Canada’s membership and participation in an increasingly globalized trade environment. Together, however, they have reoriented the focus of delivery of higher educational services toward policy efficiency rather than policy equity. ${ }^{53}$

So far, this essay has tried to establish the fiscal linkages between the federal and provincial governments in Canada and their relationship to the provision of postsecondary education. It has been argued that the federal government has used its superior fiscal position to impose national standards in an area of exclusive provincial jurisdiction, namely that of post-secondary education. Despite the simplicity in which these arrangements have been presented, these intergovernmental relationships that finance and

\footnotetext{
48 Allan M. Maslove, “The Canadian Health and Social Transfer: Forcing Issues,” How Ottawa Spends 1996-1997: Life Under the Knife, Gene Swimmer (ed) Ottawa: Carleton University Press, 1996: 284.

${ }^{49}$ Lindquist suggests the amount cut from the transfer payments to the provinces was approximately $\$ 7.9$ billion over five years, 45. Over this same period, the Canadian Association of Teachers claim the amount directed towards post-secondary education in particular, was approximately one billion dollars; in "The Funding Gap: Government Expenditures on post-secondary education, 1999- 00.” The Canadian Association of University Teachers Education Review. Vol. 3 (3) 2000: 6. Available online at: $<$ www.caut.ca/english/publications/review/education\%20review2-3.pdf>, 2001.

${ }^{50}$ Weaver, 12.

${ }^{51}$ Government of Canada, Department of Finance and Department of Supply and Services, Budget Speech, 1996, “A Focused More Affordable Government.” Available at: <http://www.fin.gc.ca/budget96/speeche/speech2e.htm >, 1996.

52 Ron Melchers, "University Finance in Canada: 1972 to the Present," Missing Pieces II: An Alternative Guide to Canadian Post-Secondary Education, Denise Doherty-Delorme and Erika Shaker eds., Ottawa: Canadian Center for policy Alternatives, 2001: 109.

${ }^{53}$ For more on the reasons why the federal government cutback the amount of public funding towards higher education, see Missing Pieces II: An Alternative Guide to Canadian Post-Secondary Education, Denise Doherty-Delorme and Erika Shaker eds., Ottawa: Canadian Center for policy Alternatives, 2001.
} 
coordinate post-secondary education in Canada are very complex ${ }^{54}$ and as such, are difficult to decipher; however, the aftermath that followed these policy shifts are quite simple. The following section examines the implications of the austerity measures Ottawa adopted toward post-secondary education.

\section{"The Demise of Universality" 55}

The changes to the level of federal funding for post-secondary education mentioned above have also affected post-secondary institutions and students. ${ }^{56}$ Kitchen $^{57}$ and others $^{58}$ for instance, argue that as federal funding began to dwindle and provincial governments decreased their funding to institutions, tuition fees have begun to increase. ${ }^{59}$ Each province was affected differently however. In fact, by 1998 a patchwork of fee levels emerged across the country. In New Brunswick for example, fees for full time undergraduates ranged from \$500 for a full course load at Mount Allison in Sackville, all the way up to $\$ 7500$ in Alberta at the University of Lethbridge for a similar workload. ${ }^{60}$

\footnotetext{
${ }^{54}$ Weaver, 13.

${ }^{55}$ This sub-title is partially borrowed from a paper written by Dr. Stephen Phillips. See title page.

${ }^{56}$ For one, the Canadian Federation of Students, the largest student advocacy group in Canada, has argued that the funding cutbacks have seriously hurt education while also driving levels of student debt to new heights. For example, in 1993, the average level of debt for a student graduating with a four year degree from a Canadian university, was $\$ 9000$. Today, that amount is approximately $\$ 25,000$, or almost three time the amount less than ten years ago. For more see, < http://www.cfs.bc.ca/>, 2002.

${ }^{57}$ Harry Kitchen, Provinces and Municipalities, Universities, Schools and Hospitals: Recent Trends and Funding Issues, Kingston Ont: Institute of Intergovernmental Relations, 313-317. Accessed through Queens University, Institute of Intergovernmental Relations, The Future of Federal-Provincial Fiscal Relations. Available at: $<$ http://www.qsilver.queensu.ca/iigr/publications/recent_publications/kitchen_chapter.pdf>, 2002.

${ }^{58}$ The Government of British Columbia, The Ministry of Advanced Education and Training, "PostSecondary Funding, Federal Spending on Post-Secondary Education: Transfers to Provinces: Trends and Consequences. Available at: <http://www.aved.gov.bc.ca/policy/>, 1999.

${ }^{59}$ Melville L. McMillan and Debasish Datta, "The Relative Inefficiencies of Canadian Universities: A DEA Perspective,” Canadian Public Policy, XXIV vol., 4 (1998): 486. Also available online at: $<$ http://www.econ.queensu.ca/pub/cpp/Dec1998/Datta.pdf>, 1998. In fact, according to the Canadian Federation of Students, the average increase of fees over the last ten years has been approximately $126 \%$, or 8 times the rate of inflation. The Canadian Federation of Students, "National Post-Secondary Issues," available at: <http://www.cfs-fcee.ca/new campaigns/\#funding $>$, 2002.

${ }^{60}$ CFSfact \#191. Available at: <www.cfs-fcee.ca/ngc/index.shtml $>$.
} 
Ontario however, has experienced the lion's share of fee hikes. According to Charlton, the average undergraduate fees have risen 60\% from 1995 to 2000 and many graduate programs have been deregulated. ${ }^{61}$ In British Columbia however, undergraduate fees have been frozen since 1995. On the whole, as the changes begin to take effect, the number of full-time post-secondary students enrolled in bachelor programs has begun to decline, especially after $1992 .{ }^{62}$ Simply stated, many of these changes have put an increased burden on provincial governments to provide sufficient funding to institutions and students alike as a way to compensate for the funding shortfalls.

\section{Where do we go from here? Concluding Comments}

This essay has examined the fiscal arrangements between Canada's two orders of government. In particular, it has emphasized their relationship to the provision of postsecondary education in Canada. From the nature of the discussion to this point, it is clear that over the course of the twentieth century, the federal government has entered into and subsequently reduced its level of involvement in this area. This is apparent simply from observing the decline to their financial commitments directed towards higher education. In this instance, the provinces have been forced to make up for much of the funding shortfalls due to their constitutional responsibilities. This occurrence has had lasting public policy ramifications and raises more questions regarding the normative and ideological doctrines guiding federal and provincial policymaking. Foremost among

\footnotetext{
${ }^{61}$ Deregulation of tuition fees refers to the process of removing all provincially imposed limits on tuition fee increases, which allows the individual institutions to set fee levels. Chris Charlton, "Ontario," Missing Pieces II: An Alternative Guide to Canadian Post-Secondary Education, Denise Doherty-Delorme and Erika Shaker eds., Ottawa: Canadian Center for Policy Alternatives, 2001: 30.

${ }^{62}$ Brigette Bouchard and John Zhao, "University education: Recent trends in participation, accessibility and returns,” Education Quarterly Review, vol., 6 (4) 2000: 25-27.
} 
concerns in this area however, is the federal government's entrance, influence, and eventual departure from an area of exclusive provincial jurisdiction.

Some would argue that since higher education is a positive externality of a market economy that optimizes the overall social welfare, governments have a responsibility to supplement that societal need. ${ }^{63}$ This seemed to be the case in the years following World War Two; however, as Canada has became increasingly reliant on the market to provide services to individuals, both levels of government began to shift their policies toward post-secondary education to reflect more of an individual or voluntary approach. In this way, the federal government has relinquished its fiduciary obligation to fund higher education to the provinces, who have then passed it on to individual institutions. Consequently, many are left with the difficult task of trying to meet increasing levels of service obligations with limited resources. For some, this may provide a partial explanation for the increased tuition fees.

In sum, changes to the funding of post-secondary education in Canada represent shifting policy priorities that have ultimately come full-circle. It has only been over the last three decades that both levels of government have began to reduce their financial commitments to institutions of higher learning, which suggests that many do not want not want the responsibility of providing post-secondary education. By funding individuals and institutions directly, the original objective of post-secondary education was oriented towards facilitating the post-war economic expansion, as the federal government supplied the economy with a steady source of skilled labour. As the economy expanded and levels of direct government funding began to decline however, market based instruments have

\footnotetext{
${ }^{63}$ Howlett, 28.
} 
crept into the public domain, which indicates that government policy towards higher education is changing to reflect the increasing importance of economic principles in the provision of public policy. In this instance, both the federal and provincial levels of government have begun to shift the provision of public services like post-secondary education to the market and funding back onto individuals. If the recent trend of funding cuts and rising tuition fees continue, higher education may once again become an exclusive policy domain for the wealthy who will be the only ones able to afford the fees in order to attend. 


\section{References}

Barker, Paul. "Disentangling the Federation: Social Policy and Fiscal Federalism.” Challenges to Canadian Federalism. Martin Westmacott and Hugh Mellon. eds. Scarborough Ont: Prentice 1998: 144-157.

Bouchard, Brigette and John Zhao. "University education: Recent trends in participation, accessibility and returns.” Education Quarterly Review. Vol. 6 (4) 2000: 24-32.

Brown, Douglas M. "Fiscal Federalism: The New Equilibrium Between Equity and Efficiency." Canadian Federalism: Performance, Effectiveness and Legitimacy. Herman Bakvis and Grace Skogstead eds. Don Mills: Oxford, 2002.

Canadian Association of University Teachers. Paul Martin and the Per Cent Solution. Available online at: <http://www.caut.ca/english/bulletin/96_oct/epf.htm>, 1996.

-----. “The Funding Gap: Government Expenditures on post-secondary education, 1999-00.” The Canadian Association of University Teachers Education Review. Vol. 3 (3) 2000: 1-10. Available online at: <www.caut.ca/english/publications/review/education\%20review2-3.pdf>, 2001.

Canadian Council on Social Development. "Thinking Ahead: Trends Affecting Public Education in the Future, Part II.” <http://www.ccsd.ca/pubs/gordon/part2.htm>, 2001.

Canadian Federation of Students, The. "National Post-Secondary Issues.” Available at: <http://www.cfs-fcee.ca/new_campaigns/\#funding>, 2002.

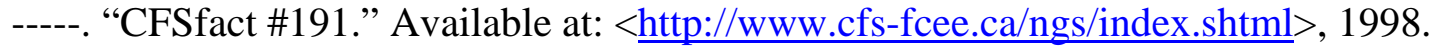

Charlton, Chris. “Ontario.” Missing Pieces II: An Alternative Guide to Canadian PostSecondary Education. Denise Doherty-Delorme and Erika Shaker eds. Ottawa: Canadian Center for Policy Alternatives, 2001: 30-33.

Coulson, Andrew J. "Market Education and the Public Good.” Can the Market Save our Schools? Claudia R. Hepburn ed. Vancouver: The Fraser Institute, 2001: 53-72. Available online at: $<$ http://www.fraserinstitute.ca/publications/books/market_schools/5_coulson.pdf $>$, 2001.

Dickson, Vaughan, William J. Milne and David Murrell. "Who Should Pay for University Education? Some Net Benefit Results by Funding Source for New Brunswick." Canadian Public Policy. Vol., XXII (4) 1996: 315-329.

Dyck, Rand. Canadian Politics: Critical Approaches. $2^{\text {nd }}$ ed. Scarborough: Thompson, 1996. 
Gagnon, Alain G. “The Political Uses of Federalism.” New Trends in Canadian Federalism. Francois Rocher and Miriam Smith. Eds. Peterborough Ont: Broadview, 1995: 23-45.

Government of British Columbia. The Ministry of Advanced Education and Training. "PostSecondary Funding.” Federal Spending on Post-Secondary Education: Transfers to Provinces: Trends and Consequences. Available at: $<$ http://www.aved.gov.bc.ca/policy/>,1999.

Government of Canada. Human Resources Development Canada, Industry Canada and Council of Ministers of Education Canada. A Report on Public Expectations of Postsecondary Education in Canada. Council of Ministers of Education, Canada. Toronto: 1999.

Government of Canada. b. Department of Finance and Department of Supply and Services. Budget Speech, 1996, “A Focused More Affordable Government.” Available at: <http://www.fin.gc.ca/budget96/speeche/speech2e.htm>, 1996.

Hobson, Paul A. R. and France St. Hilaire. The Evolution of Federal-Provincial Fiscal Arrangements: Putting Humpty Together Again. Kingston: Institute for Intergovernmental Relations, 1999. Queens University, Institute for Intergovernmental Relations, Working Paper Series. Available at: $<$ http://qsilver.queensu.ca/iigr/publications/recent_publications/hobson_st_hilaire_ch apter.pdf>, 159-188.

Howlett, Michael and M. Ramesh. Studying Public Policy: Policy Cycles and Policy Subsystems. Don Mills ONT: Oxford, 1995.

Hum, Derek and Frank Strain. "Fiscal Transfers, Horizontal Equity and Post-Secondary Education. The Canadian Journal of Higher Education. XVIII (2): 1988, 14-37.

Kitchen, Harry. Provinces and Municipalities, Universities, Schools and Hospitals: Recent Trends and Funding Issues. Kingston Ont: Institute of Intergovernmental Relations, n.d. Accessed through Queens University, Institute of Intergovernmental Relations, The Future of Federal-Provincial Fiscal Relations $<\underline{\text { http://www.qsilver.queensu.ca/iigr/publications/recent publications/kitchen chapter.pdf }>}$ 2002.

Lazar, Harvey. "In Search of a New Mission Statement for Canadian Fiscal Federalism.” Canada: The State of the Federation (1999/2000): Toward a New Mission Statement for Canadian Fiscal Federalism. Harvey Lazar. Ed. Kingston Ont: Institute of Intergovernmental Relations, 1999: 3-39. Available online at: $<$ http://qsilver.queensu.ca/iigr/publications/recent_publications/lazar_mission_statem ent.pdf $>$.

Levin, Benjamin and Nancy Sullivan. "Governments and Universities.” The Canadian Journal of Higher Education. Vol. XVIII (1): 1998, 1-5. 
Maslove, Allan M. “The Canadian Health and Social Transfer: Forcing Issues.” How Ottawa Spends 1996-1997: Life Under the Knife. Gene Swimmer (ed) Ottawa: Carleton University Press, 1996: 283-301.

McMillan, Melville L and Debasish Datta. "The Relative Inefficiencies of Canadian Universities: A DEA Perspective.” Canadian Public Policy, XXIV vol., 4 (1998): 485-511. Also available online at: <http://www.econ.queensu.ca/pub/cpp/Dec1998/Datta.pdf>, 1998.

Melchers, Ron. "University Finance in Canada: 1972 to the Present." Missing Pieces II: An Alternative Guide to Canadian Post-Secondary Education. Denise DohertyDelorme and Erika Shaker eds. Ottawa: Canadian Center for policy Alternatives, 2001: 109-117.

Redden, Candace. Through the Looking Glass: Federal and Provincial Decision-Making for Health Policy. Kingston: Institute for Intergovernmental Relations, 1999. Available at: Queens University, Institute for Intergovernmental Relations, Working Paper Series.

$<$ www.qsilver.queensu.ca/iigr/publications/working_paper_series/Redden.html>. 1999.

Ruggeri, G.C. "Vertical Fiscal Imbalances and Renewed Federalism.” Policy Options (Nov 1998): 47-49.

Sibley, W.M. “The University in the 1990’s: Crisis or Predicament?” The Canadian Journal of Higher Education. Vol. XXIII (1): 1993, 114-131.

Tapscott, Don. “Rethinking the University.” Policy Options (July-August 1998): 67-71.

Telford, Hamish. The Federal Spending Power in Canada: Nation-Building or NationDestroying? Kingston: Institute of Intergovernmental Relations, 1999. Accessed through Queens University, Institute of Intergovernmental Relations, Working Paper Series. <http://www.qsilver.queensu.ca/iigr/>, 2002.

Weaver, Paul. Fiscal Federalism and Social Policy in Canada: The Financing of Structural Adjustment. Term Paper for POL 324, SFU: 2002.

Wotherspoon, Terry. "The Dynamics of Social Inclusion and Exclusion in Public Education in Canada." Canadian Council for Social Development. <http://www.ccsd.ca/subsites/inclusion/bp/tw.htm>, 2001.

Whittington, Michael and Richard J. Van Loon. Canadian Government and Politics: Institutions and Processes. Toronto: McGraw-Hill Ryerson, 1996.

Whereare, K.C. Federal Government. $4^{\text {th }}$ Ed. London: Oxford University Press, 1963. 